\title{
CYTOTOXICITY OF CLINACANTHUS NUTANS EXTRACTS ON HUMAN HEPATOMA (HepG2) CELL LINE
}

\author{
HAZRULRIZAWATI ABD HAMID*, IZZAH HAYATI YAHAYA
}

Faculty of Industrial Sciences and Technology, Universiti Malaysia Pahang, Lebuhraya Tun Razak, 26300 Gambang Kuantan, Pahang, Malaysia Email: hazrulrizawati@ump.edu.my

Received: 23 Jun 2016 Revised and Accepted: 12 Aug 2016

\section{ABSTRACT}

Objective: Clinacanthus nutans is one of the herbs that has been used in Asia as a traditional medicine for the treatment of serious diseases. The aim of this study is to investigate the phytochemical constituents (flavonoids and phenolics) and cytotoxicity against human hepatoma (HepG2) cancer cell lines of $C$. nutans extracts.

Methods: The fractions from C. nutans were extracted from hexane, methanol, chloroform and ethyl acetate by the solvent-solvent extraction method. The crude extracts $(10 \mathrm{mg} / \mathrm{ml})$ were tested against HepG2 cell lines using 3-(4, 5-dimethylthiazol-2-yl)-2,5-diphenyltetrazolium bromide (MTT) assay. Phytochemical screening was done to determine the total phenolic content (TPC) and total flavonoid content (TFC).

Results: Methanol extract showed the strongest cytotoxic activity against HepG2 cell line with IC 50 of $43.9367 \mu \mathrm{g} / \mathrm{ml}$ after $24 \mathrm{~h}$ of treatment compared to chloroform extract and ethyl acetate, $55.6112 \mu \mathrm{g} / \mathrm{ml}$ and $62.0655 \mu \mathrm{g} / \mathrm{ml}$, respectively. Hexane extract formed the lowest cytotoxicity activity with IC 50 of $68.3807 \mu \mathrm{g} / \mathrm{ml}$. Total phenolic content (TPC) was found to be highest in chloroform, which was $119.29 \mathrm{mg}$ of gallic acid equivalent (GAE) and total flavonoid content (TFC), methanol was performed the highest value, which is $937.67 \mathrm{mg}$ of butylated hydroxytoluene (BHT).

Conclusion: Different active compounds present in the extracts may contribute different cytotoxicity effects of crude extracts. The relationship data of total phenolic, total flavonoid, and cytotoxic potential of $C$. nutans, indicates that these plants might contain valuable active compounds as a chemotherapeutic agent. Further investigations to elucidate the chemical structures of active compounds are necessary for potential compounds discovery in drugs.

\section{Keywords: Clinacanthus nutans, Cytotoxicity, Human hepatoma (HepG2) cell line}

(C) 2016 The Authors. Published by Innovare Academic Sciences Pvt Ltd. This is an open access article under the CC BY license (http://creativecommons. org/licenses/by/4. 0/) DOI: http://dx.doi.org/10.22159/ijpps.2016v8i10.13626

\section{INTRODUCTION}

Cancer is the most distressing and life-threatening disease that enforces severe death worldwide [1]. Moreover, Cancer remains as one of the major health threats to Malaysians with a yearly mortality rate of cancer patients that has consistently reached $10-11 \%$ [2]. Current treatments including radiotherapy and chemotherapy are mostly ineffective against advanced stages of cancer and associated with severe side effects. [1] In addition, these treatments are not selective of cancerous cells and their therapeutic efficiency is limited due to the damage they can cause to healthy cells and tissues. To avoid these side effects in cancer therapy, there is an urgent need to develop therapeutic modalities with no or minimal side effects to normal organs. Use of plants for therapy is not new; indeed plants have been considered a valuable source of bioactive compounds for the treatment of many conditions, including cancer, in almost all cultures and communities for thousands of years [3].

Nowadays, there is a lot of research being done on the importance of medicinal plants for healing process compared to the existence of medicinal synthesize from the chemical. Herbs are one of in the types of plants, and some herbs have potential to cure serious diseases. In Indonesia, where herbal medicine is popular, more than 1300 species are known as medicinal plants, called Jamu [4]. These traditional herbal medicines still play an important role in the treatment of illnesses. C. nutans is one of the herbs that has been used in Thailand as a traditional medicine for the treatment of serious diseases [5]. C. nutans belongs to the family of Acanthaceae, which are known to have medicinal properties. This plant can be found in Malaysia, Thailand and Vietnam [6].

Previous phytochemical studies from $C$. nutans led to the isolation of flavonoids, steroids, triterpenoids, cerebrosides, glycol glycerollipids, glycerides, sulfur-containing glyceride from this plant $[5,7]$. $C$. nutans has a viral potential for treatment of skin rashes, insect, and snakebite, herpes simplex virus (HSV), and varicella-zoster virus
(VZ) $[7,8]$. Moreover, previous studies reported that the chloroform extract from $C$. nutans are good in antioxidant against $\alpha$-diphenyl- $\beta-$ dipicryl-hydrazyl (DPPH) and galvinoxyl radicals and exert a high antiproliferative effect on human leukemia (K-562) cell line [2]. Although other researchers, but none of the reports has reported cytotoxicity of $\mathrm{C}$. nutans in different doses, time and solvent extraction was tested on human hepatoma (HepG2) cell line. Apart from these reports, the correlation between cytotoxicity and phytochemicals contents may provide potential lead compounds in drug discovery. Thus, the aim of this work is to screen the total phenolic content (TPC), total flavonoid content (TFC) of the four different extracts and cytotoxicity toward human hepatoma (HepG2) cell line.

All solvents used were of analytical grade and included: methanol,chloroform, ethyl acetate, and hexane (Merck, Darmstadt, Germany). Folin-Ciocalteu phenol reagent, gallic acid, butylated hydroxytoluene, Roswell Park Memorial Institute medium (RPMI), fetal bovine serum (FBS), penicillin and streptomycin were purchased from Sigma-Aldrich Co. (St. Louis, MO, USA). Ultraviolet (UV) spectra were recorded on a microplate reader (Tecan Infinite 200 Pro).

The dried powder was percolated with hexane (Fraction I) followed by methanol for a day. Both extracted plant samples were sonicated in $30 \mathrm{~min}$ over three cycles. Hexane (Fraction I) and methanol extraction (Fraction II) were filtered. The filtrates were evaporated to dryness using a rotary evaporator at a temperature below than 60 ${ }^{\circ} \mathrm{C}$ and with low pressure. Next, methanol extract was mixed with water in a ratio 3:1 and activated charcoal is a function to remove excessive chlorophyll before fractionate by dissolving the mixture with chloroform producing chloroform phase (Fraction III) and an aqueous phase, thrice. Then, ethyl acetate was added into the aqueous phase, thrice to obtained ethyl acetate phase (Fraction IV) and an aqueous phase. The extracts were concentrated in vacuo and evaporated using a rotary evaporator to get crude extractions. 
TPC of C. nutans extract was determined by a method developed by [9]. A stock solution of plant extracts was prepared in methanol and pipetted out into test tube and mixed with $0.5 \mathrm{ml}$ of Folin-Ciocalteu phenol reagent was added (FC reagent was dissolved in distilled water with 1:1 ratio). Then $2.5 \mathrm{ml}$ of $20 \%$ sodium carbonate was added in each tube and finally the mixture was mixed properly by using vortex and then the test tube was kept in the dark for 40 min. Absorbance spectra was recorded at $725 \mathrm{~nm}$ using glass cuvettes. To minimize standard error, the reaction was tested thrice and the results were expressed in milligrams of gallic acid equivalent (mg GAE).

Total flavonoid content of plant extracts was determined by [9]. Concisely, $100 \mu \mathrm{l}$ of each plant extract $(1 \mathrm{mg} / \mathrm{ml})$ was dissolved in corresponding solvents and then the extracts were made up to $1 \mathrm{ml}$ by using distilled water followed by the addition of $75 \mu \mathrm{l}$ of $10 \%$ sodium nitrate solution. After a $6 \mathrm{~min}$ interval, $150 \mu \mathrm{l}$ of $5 \%$ aluminium chloride solution was added, and then $0.5 \mathrm{ml}$ of $1 \mathrm{M}$ $\mathrm{NaOH}$ was added in the test tubes. The mixture samples were added up to $2.5 \mathrm{ml}$ by using distilled water and thoroughly mixed. The UV$V$ absorbance values were read immediately at $510 \mathrm{~nm}$. The results were expressed in $\mathrm{mg} / \mathrm{g}$ butylated hydroxytoluene (BHT) equivalents. Four different extracts, Fraction I, Fraction II, Fraction III and Fraction IV were tested on human liver hepatocellular carcinoma (HepG2) for their anticancer activity. The cell lines were stored in Roswell Park Memorial Institute medium (RPMI) medium containing $10 \%(\mathrm{v} / \mathrm{v})$ fetal bovine serum (FBS) supplemented with penicillin $(100 \mathrm{U} / \mathrm{ml})$ and streptomycin $(100 \mu \mathrm{g} / \mathrm{ml})$ under humidified atmosphere containing $5 \% \mathrm{CO}_{2}$ in the incubator.

$1 \mathrm{mg}$ of four extracts was dissolved in $1 \mathrm{ml}$ of $0.1 \%$ of DMSO (with distilled water) as a stock solution of $0.1 \mathrm{mg} / \mathrm{ml}$ respectively. The testing solutions were made by half series dilution from $0 \mu \mathrm{g} / \mathrm{ml}$ to $100 \mu \mathrm{g} / \mathrm{ml}(0,6.25,12.5,25,50,100 \mu \mathrm{g} / \mathrm{ml})$. These crude extracts were used for MTT assay
For the MTT assays cells $(10 \mu \mathrm{l})$ were added into all the wells (104105 cells per well) with various concentration of extracts and incubated in a $37^{\circ} \mathrm{C}, \mathrm{CO}_{2}$ incubator for $24 \mathrm{~h}$. A stock solution of 10 $\mathrm{mg} / \mathrm{ml}$ MTT was prepared in PBS and MTT reagent $(20 \mu \mathrm{l})$ was added to the cell monolayer. During this period, the living cells produced insoluble blue formazan from yellow soluble MTT. The reaction was stopped by the addition of dimethyl sulfoxide (DMSO, $100 \mu \mathrm{l})$ in each well. Control cells were incubated without the extract and with DMSO. The absorbance of samples was read at $540 \mathrm{~nm}$ using microplate reader.

Experiments were performed thrice. Results were expressed as percentage growth inhabitation of control. The percentage of inhibition of cell lines was calculated as shown below:

$$
\% \text { Inhibition }=100-\left[\frac{A b s_{\text {sample }}-A b s_{\text {blank }}}{A b s_{\text {control }}-A b s_{\text {blank }}}\right] \times 100
$$

The IC 50 values for each of the active extracts were determined by plotting the percentage inhibition values against the concentration of the extracts. A dose-response curve was used to enable the calculation of the concentrations that killed $50 \%$ of the HepG2 cells $\left(\mathrm{IC}_{50}\right)$. The results were expressed as mean \pm SD. One-way ANOVA was determined the concentration of extracts against the percentage of growth inhibition

Healthy HepG2 cells that achieved confluence were used in this assay. HepG2 cells exhibited epithelial-like structure to the bottom of the flask. The percentage inhibition of $C$. nutans extracts on HepG2 cell line after $24 \mathrm{~h}$ of treatment as shown in table 1 . The data shows that methanol extract performed the highest percentage of inhibition (74.17\%) against hepG2 cell line followed by ethyl acetate extract (69.67\%), chloroform extract $(64.80 \%)$ and hexane extract (61.67\%) at a concentration of $100 \mu \mathrm{g} / \mathrm{ml}$.

Table 1: Percentage inhibition of Clinacanthus nutans extracts on HepG2 cell line after 24h of treatment

\begin{tabular}{lllll}
\hline Extracts & \% inhibition at different concentration $(\boldsymbol{\mu g} / \mathbf{m l})$ & $\mathbf{2 5}$ & $\mathbf{5 0}$ \\
\cline { 2 - 5 } & $\mathbf{6 . 2 5}$ & $\mathbf{1 2 . 5}$ & $42.50 \pm 0.83$ & $43.75 \pm 0.06$ \\
Hexane & $11.67 \pm 0.24$ & $20.00 \pm 0.32$ & $47.63 \pm 0.68$ & $60.00 \pm 0.81$ \\
Methanol & $10.58 \pm 0.27$ & $24.17 \pm 0.39$ & $34.92 \pm 0.60$ & $54.16 \pm 0.75$ \\
Chloroform & $10.23 \pm 0.75$ & $28.10 \pm 0.45$ & $39.67 \pm 0.73$ & $74.17 \pm 0.50$ \\
Ethyl Acetate & $10.10 \pm 0.57$ & $22.86 \pm 0.38$ & $68.46 \pm 0.91$ & $69.67 \pm 0.44$ \\
\hline
\end{tabular}

$n=3$; Values have been expressed as mean \pm standard deviation

The evaluation of cytotoxicity was done using the dose-response curve obtained by non-linear regression analysis. The $\mathrm{IC}_{50}$ values of all extracts are summarized in table 2 . The percentage of inhibition of HepG2 cells is directly proportional as the extracts concentration increases. Methanol extract exhibited higher cytotoxicity on HepG2 cells after $24 \mathrm{~h}$. The results obtained shows that methanol extract exhibited the strongest cytotoxicity activity against HepG2 cells line after a $24 \mathrm{hr}$ treatment with IC50 of $43.9367 \mu \mathrm{g} / \mathrm{ml}$ followed by chloroform extract and ethyl acetate, $55.6112 \mu \mathrm{g} / \mathrm{ml}$ and $62.0655 \mu \mathrm{g} / \mathrm{ml}$, respectively. Hexane extract performed the lowest cytotoxicity activity with IC50 of $68.3807 \mu \mathrm{g} / \mathrm{ml}$.

Table 2: IC 50 values of Clinacanthus nutans crude extracts against HepG2 lines at $24 \mathrm{~h}$ incubation

\begin{tabular}{lll}
\hline Cell line & Extracts & $\mathbf{I C}_{\mathbf{5 0}}$ values $(\boldsymbol{\mu g} / \mathbf{m l})$ \\
\hline HepG2 & Hexane & $68.38 \pm 0.07$ \\
& Methanol & $43.93 \pm 0.05$ \\
& Chloroform & $55.61 \pm 0.03$ \\
& Ethyl Acetate & $62.06 \pm 0.06$ \\
\hline
\end{tabular}

$\mathrm{n}=3$; Values have been expressed as mean \pm standard deviation

Table 3: Total phenolic content (TPC) and total flavonoid content (TFC) of C. nutans from four different type of solvent

\begin{tabular}{lll}
\hline Solvent extracts & Total phenolic content $(\mathbf{m g} / \mathbf{G A E})$ & TotalFlavonoid content $\mathbf{( m g / g )}$ \\
\hline Standard & $250.57 \pm 0.07^{*}$ & $533.22 \pm 0.04^{\#}$ \\
Hexane & $28.25 \pm 0.02$ & $586.67 \pm 0.01$ \\
Ethyl Acetate & $22.17 \pm 0.02$ & $532.33 \pm 0.02$ \\
Chloroform & $119.29 \pm 0.07$ & $428.67 \pm 0.03$ \\
Methanol & $53.91 \pm 0.03$ & $937.67 \pm 0.02$ \\
\hline
\end{tabular}

$\mathrm{n}=3$; Values have been expressed as mean \pm standard deviation, ${ }^{*}$ Gallic acid\# $\alpha$-BHT 


\section{Total phenolic content (TPC) and total flavonoid content (TFC)}

The total of phenolic content (TPC) was found to be highest in the chloroform extract, which is $119.29 \mathrm{mg}$ of GAE/g compared to other extracts. Total of flavonoid content (TFC), methanol crude performed the highest value, which is $937.67 \mathrm{mg}$ of BHT/g compared with hexane and Ethyl Acetate, which are 586.67 \pm 0.001 $\mathrm{mg} / \mathrm{g}$ and $532.33 \pm 0.0002 \mathrm{mg} / \mathrm{g}$ respectively. This chloroform extract had the lowest value $(428.67 \pm 0.003 \mathrm{mg} / \mathrm{g})$ (refer table 3$)$

The methanol extract from $C$. nutans showed the highest cytotoxicity effect compared to hexane, chloroform, and ethyl acetate extracts. Possibly, the activity might be due to the total flavonoid content which are highest in methanol extract. Methanol extracts treated with HepG2 cells, the $\mathrm{IC}_{50}$ values was $43.9367 \mu \mathrm{g} / \mathrm{ml}$, which was above the recommended $\mathrm{IC}_{50}$ value by National Cancer Institute of America, for crude extract, which is $<30 \mu \mathrm{g} / \mathrm{ml}$ [10]. Although this data suggests that methanol extract from $C$. nutans may not be a strong anticancer regimen, cancer inhibitory properties shown in this experiment may still support the use of $C$. nutans as an alternative adjunctive therapy for cancer prevention or treatment.

A similar study was reported by [6] that methanol extract from $C$. nutans yield sub-fraction F-III. Sub-fraction F-III inhibited the growth of all 4 cell line HepG2, NCI H460, MCF-7 and Hela. Subfraction F-III got the highest cytotoxicity with $\mathrm{IC}_{50}$ of $36.80 \mu \mathrm{g} / \mathrm{ml}$ against HepG2 cell line compared to other cell lines.

In previous studies, Muhammad (2014) [5] claimed that six known C-glycosyl flavones were found in methanol extract that has been isolated earlier in the study. Flavonoid is a sub-class of phenolic and known with its polyphenolic structures. Flavonoids play an important role in protecting biological systems against harmful effects of oxidative processes on macromolecules [11]. Apart from the ability of a substance to modulate several biological activities, its direct interaction with cells in vivo can result in toxic effects [12].

Different flavonoids and phenolic compounds react with free radicals to reduce the degradation of membranes by preventing the reaction between free radicals and phospholipids [13]. Flavonoids are reported to possess antiulcer activity, hepatoprotective activity, anti-inflammatory activity, antidiabetic effects, vasorelaxant process, anti-atherosclerotic effects, anti-thrombogenic effects, cardioprotective effects and anti-neoplastic activity. Flavonoids are also known to possess antibacterial properties.

In conclusion, the methanol extract exhibited the strongest cytotoxic activity against HepG2 amongst all the $C$. nutans extracts with a high total flavonoid content. Based on these results, study are ongoing to determine the chemical profiling of flavonoids in methanol extract by using UPLC/QToF-MS. A major content of flavonoids may be utilized as an anticancer pharmaceutical application.

\section{ACKNOWLEDGEMENT}

Support for this work was provided by Ministry of Education via a research grant (RDU 140102).

\section{CONFLICTS OF INTERESTS}

Declared none

\section{REFERENCES}

1. Krishnakumar N, Sulfikkarali N, Rajendra Prasad N, Karthikeyan S. Enhanced anticancer activity of naringeninloaded nanoparticles in human cervical (HeLa) cancer cells. Biomed Preventive Nutr 2011;1:223-31.

2. Yong YK, Tan JJ, Teh SS, Mah SH, Ee GCL, Chiong HS, et al. Clinacanthus nutans extracts are antioxidant with antiproliferative effect on cultured human cancer cell lines. J Evidence-Based Complementary Altern Med 2013;9. http://dx.doi.org/10.1155/2013/462751

3. Ochwang'i DO, Kimwele CN, Oduma JA, Gathumbi PK, Mbaria JM, Kiama SG. Medicinal plants used in treatment and management of cancer in Kakamega County, Kenya. J Ethnopharmacol 2014;151:1040-55.

4. Roosita K, Kusharto CM, Sekiyama M, Fachrurozi Y, Ohtsuka R. Medicinal plants used by the villagers of a Sundanese community in West Java, Indonesia. J Ethnopharmacol 2008;115:72-81.

5. Aslam MS, Ahmad MS, Mamat AS. A review on phytochemical constituents and pharmacological activities of Clinacanthus nutans. Int J Pharm Pharm Sci 2014;7:30-3.

6. Dan PNM. Evaluation of biological activities of Clinacanthus nutans (Burm. F.) lindau: International University, Vietnam; 2014.

7. Sakdarat S, Shuyprom A, Pientong C, Ekalaksananan T, Thongchai S. Bioactive constituents from the leaves of Clinacanthus nutans Lindau. Bioorg Med Chem 2009;17:1857-60.

8. Lai HY, Ong SL, Rao NK. In vitro lipase inhibitory effect of thirtytwo selected plants in Malaysia. Asian J Pharm Clin Res 2014;7:19-24.

9. Kuppusamy P, Yusoff MM, Parine NR, Govindan N. Evaluation of in vitro antioxidant and antibacterial properties of Commelina nudiflora $L$. extracts prepared by different polar solvents. Saudi J Biol Sci 2015;22:293-301.

10. Roslen NA, Alewi NAM, Ahamada H, Rasad MSBA. Cytotoxicity screening of Melastoma malabathricum extracts on human breast cancer cell lines in vitro. Asian Pacific J Trop Biomed 2014;4:545-8.

11. Peng TW, P'ng Xiu Wen CJ, Han GAA. Effect of methanol extract of Clinacanthus nutans on serum biochemical parameters in rats. J Appl Pharm 2014;1:77-86.

12. Soares V, Varanda EA, Raddi M. In vitro basal and metabolismmediated cytotoxicity of flavonoids. Food Chem Toxicol 2006;44:835-8.

13. Van Der Watt E, Pretorius JC. Purification and identification of active antibacterial components in Carpobrotus edulis L. J Ethnopharmacol 2001;76:87-91.

\section{How to cite this article}

- Hazrulrizawati Abd Hamid, Izzah Hayati Yahaya. Cytotoxicity of Clinacanthus nutans extracts on human hepatoma (HepG2) cell line. Int J Pharm Pharm Sci 2016;8(10):293-295. 